\title{
The Development of a Questionnaire for the Objective Measurement of Belief or Knowledge Motivation i.S. an Intrapsychic Behavioral Guide
}

\author{
Dipl Psych Josef Wacker \\ Department of Psychotherapy, TH Dortmund University, Arnsberg, Germany
}

Email address:

dr.josef.wacker@unitybox.de

\section{To cite this article:}

Dipl Psych Josef Wacker. The Development of a Questionnaire for the Objective Measurement of Belief or Knowledge Motivation i.S. an Intrapsychic Behavioral Guide. American Journal of Applied Psychology. Vol. 8, No. 2, 2019, pp. 27-35. doi: 10.11648/j.ajap.20190802.11

Received: January 26, 2019; Accepted: April 27, 2019; Published: June 10, 2019

\begin{abstract}
The self-developed psychological test instrument: Questionnaire for recording a Beliefsystem (FEB) is a selfevaluation questionnaire with 14 items. With the help of this questionnaire the individual, latent, inner attitude mata, a kind of motive in the sense of "need to know" or "want to believe" should be determined. On the basis of the results of theFactor analyses, theFactor correlations and the reliability calculations, we can state, according to the criteria of classical test theory, that theFEB is a test which is also capable of measuring the theoretical constructs mentioned above in a valid and reliable manner.
\end{abstract}

Keywords: Faith Motivation, Knowledge Motivation, Self-Assessment, Motives

\section{Introduction}

In order to find out why anxious and/or depressed people need to know, rather than believe, why they would be able to do so mentally but do not, it is important to develop an instrument that measures something like an inner cognitive schema or central need (motivation) validly and reliably.

The development of a questionnaire which on the one hand measures something like faith in the sense of an intrapsychic behavioural instruction, comparable to an inner need or an individual motivation to act and on the other hand must have knowledge as an alternative to it, turned out to be quite difficult, since the definitions of faith and knowledge could not be clearly determined from an epistemological point of view or scientific knowledge.

With the term "faith" there are no clear scientific statements about what "faith" is. To date, science has owed an exact definition, or operationalization, of this term. But here also no scientifically correct statements and definitions of faith are to be presented and discussed, that would go beyond the scope. In addition, this is about the development of a measuring instrument. It is only about a short representation of faith as the ability and/or willingness of man to create, move or change things in himself and his power. Cf [1-41]

But it makes sense to give a few simple explanations about the terms to be measured with the test procedure at this point.

\subsection{General Meaning of Faith}

In common parlance, believing means believing a fact to be true. This is a presumption, an assumption of which an individual is convinced without realistically examining the facts of the case, but which can be modified on the basis of experience and new findings by means of a subjunctive link. This kind of inner conviction implies a trust in an

or a sentence without doubting the truth. It thus represents a subjective decision based on an emotionally perceived certainty.

In general, people only believe in what they do not know explicitly, i.e. where they are uncertain. Here faith always presupposes a degree of ignorance, a possibility to err.

The proverbs: "Faith means knowing nothing", or "Trust is good, control is better" are still frequently used in everyday language today. As wise as these statements may seem a priori, they misjudge the true character of these concepts, because they imply that faith means only to assume something or to blindly believe something to be true.

In the scientific sense, faith is usually regarded as a special 
form of a probabilistic construct. This means that scientists assume that what they believe in can become true over time, but does not have to become true. It is therefore a matter which has not yet been proven in the scientific sense and which must first be proven, or which cannot be proven at all. Explicitly, this form of faith is an assumption, a hypothesis that is confirmed or rejected according to the criteria of verification and/or falsification. As already explained above, "belief" in the sense of epistemology means the advocacy of one's own convictions or perceptions. The resume from the resulting does not necessarily require a logical derivation in the epistemological sense. Insted, it is a subjective interpretation of the reality that surrounds us, which does not require any objective, scientific justification.

\subsection{General Meaning of Knowledge}

In colloquial terms, knowledge is primarily understood to mean an ability to deal with reality, e.g. to have some knowledge, developed through learning and practice of what has been learnt. In other words, knowledge also means the recognition of the connections between everyday, subjective and objective facts and actions. Here knowledge is understood primarily as a true and justified opinion.

Within philosophy there is no agreement on an exact definition of the term "knowledge". This disagreement is the logical, consistent consequence within Western attempts at epistemological explanation, because in this philosophical approach the term knowledge was linked with the term truth.

The conflict between a priori knowledge $(42,43)$ and empirical knowledge 44 which is always mentioned in this context, points to the centuries-long conflict. For Plato there existed a knowledge, independent of sensory perceptions, which was exclusively acquired by logical derivations in deductive reasoning. A rationalist was therefore someone who "attaches more importance to pure thought for knowledge than to experience" 45 . This rationalist approach to the definition of knowledge found its most important advocate in René Descartes in rationalism. He already separated strictly between the empiricism of the "res extensia" and the "res cogitans" of the spiritual. The philosopher Arendt summed up that such a Cartesian juxtaposition of a "res cogitans" of man and a "res extensia" of the world surrounding him was incurable 46 Also the later philosophies (Critical Rationalism and Logical Empirism cf. $(47,48)$, in German 2007, and the works of $(49,50,51,52$, 53) or the philosophers of the Vienna Circle: Moritz Schlick, Ludwig Wittgenstein, Rudolf Carnap, Bertram Russell and Ernst Mach, in: 54 But also the findings of constructivism and logical constructivism see $(55,56,57,58,5960,61,62$, $63,64)$ did not bring an unambiguous and clear scientific definition of the term "knowledge".

\section{The Item Development}

Because there are no clear scientific definitions of the terms "faith" or "knowledge" to date, items have been developed that have been used in colloquial usage, in the form of proverbs, from everyday life. Like, for example: "Faith moves mountains," or "knowledge is power." Through several years of psychotherapeutic experience in dealing with anxious and depressed patients, it could be established that faith no longer seemed to play any role für this clientele, let alone any function for a consciously chosen problem solving strategy. Instead, this clientele emphasized time and again that believing in sonething had never helped them in their way of life. I On the contrary, they would only associate faith with bad experiences (losses, insults and disappointments).

According to these people, "control is better than trust". "Faith is for children, the don't have to know everything." When asked why knowledge was more important to them than faith, most responded that knowledge was synonymous with "assumptions", "naivety", or "helplessness".

Through an analysis of the reason for the rejction of faith, as opposed to the clear preference for knowledge, it was possible, at least partially, to define the meaning of these terms for this group of people somewhat more clearly. Based on this understandig, further test items were developed which could also be able to measure thes terms. Using well-known proverbs like: "Trust is good, control is better", "knowledge is power" or "faith moves mountains", 14 different items were formulated. To what extent the statement of the individual item corresponds or does not correspond to the individual pattern of thinking or behaviour could the test persons choose between 4 answer categories: "not true", "true something", "often true" and "always true". (seeFEB questionnaire in annex).

\subsection{Testapproval}

The self-evaluation questionnaire designed in this way was distributed to $150 \mathrm{Vpn}$ (50 inconspicuous, 50 anxious and 50 depressive persons) and willingly completed by them in accordance with the instructions formulated in the test.

\subsection{Statistical Test Analysis}

In order to check whether this questionnaire measures something like a theoretical construct "Belief systems" as a personal decision basis in the sense of "can believe" or "must know" aFactor analysis with main component analysis as extraction method and with Varimax Kaiser normalization as rotation method was calculated. Absolute values below - -500 were not taken into account. TheFactor analysis was created using the SPSS program (version: 23.0) on the computer with Windows 7.

\subsection{Results ofFactor Analyses and Regression Calculations}

In order to be able to make a reliable statement about the theoretical construct "Belief Systems", i.e. about the validity of the test instruments, according to the classical test criteria, a 3-factor solution and a 2-factor solution were calculated (see Table 1). 
Table 1. Explained total variance of the 3-factor solution.

\begin{tabular}{lllllll}
\hline \multirow{2}{*}{ component } & \multicolumn{2}{l}{ Initial eigenvalues } & & \multicolumn{3}{l}{ Sums of squared Factor charges for extraction } \\
\cline { 2 - 7 } & Total & \% of variance & Accumuleted\% & Total & \% of variance & Accumuleted\% \\
\hline 1 & 5,210 & 40,076 & 40,076 & 5,210 & 40,076 & 40,076 \\
2 & 1,696 & 13,044 & 53,120 & 1,696 & 13,044 & 53,120 \\
3 & 1,010 & 7,773 & 60,893 & 1,010 & 7,773 & 60,893 \\
\hline
\end{tabular}

Extraction Method: Principal Component Analysis.

As can be seen from the table, the 3 Factors with the eigenvalues 5.210 (factor 1), 1.696 (factor 2) and 1.010 (factor 3 ) explain $60.893 \%$ of the total variance.

If we look at the following rotated component matrix with the individual items and theirFactor charges we can see that 6 items (No. 3, 4, 5, 10, 12 and 14) load on the $1^{\text {st }}$ Factor and that with very high charges. Which could mean that these questions measure something like "a motiv need knowledge" as a commonFactor. The "faith item" No. 11 also loads on the firstFactor, but negatively, which could mean that conversely knowledge would be more important than imagination. Items Nos. 2, 6, 7, 8 and 9 load on the $2^{\text {nd }}$ Factor, which, if one looks for a higher dimension for these different items, could measure something like a motive of faith. Only item no. 1 with the highestFactor charge $(, 837)$ loads on the $3^{\text {rd }}$ Factor. What thisFactor explicitly measures is difficult to answer due to the single item without becoming speculative. Maybe it is also because it is the only item that is formulated negatively and therefore loads on only oneFactor. (see Table 2)

Table 2. Rotated component matrix.

\begin{tabular}{lll}
\hline & Komponente & $\mathbf{1}$ \\
\hline FEB Question 14 Knowledge make safe &, 803 \\
FEB Question 3 Double stitched holt better &, 782 \\
FEB Question 10 Trust is good, control is better &, 745 \\
FEB Question 12 I only belief what i see &, 728 \\
FEB Question 5 safe is safe &, 671 \\
FEB Question 11 Fantasy is more important than knowledge &, 659 \\
FEB Question 4 Knowledge is more important than faith &, 623 \\
FEB Question 6 Faith moves mountains &, 775 \\
FEB Question 9 Conifidence gives courage &, 735 \\
FEB Question 7 Hope dies last &, 707 \\
FEB Question 8 Dreams come true &, 632 \\
FEB Question 2 Optimists live easier &, 623 \\
FEB Question 1 1 Faith means to know nothing &, 837 \\
\hline
\end{tabular}

Extraction method: principal component analysis.

Rotation method: Varimax with Kaiser normalization.

In order to clarify whether there is a relationship between the individualFactors or whether they are independent of each other, aFactor correlation was calculated according to Pearson. (see Table 3).

Table 3. Correlation of the 3-factor solution.

\begin{tabular}{lllll}
\hline & & Factor 1 & Factor 2 & Factor 3 \\
\hline \multirow{2}{*}{ Factor 1 } & Correlation according to Pearson & 1 &,$- 437^{* *}$ &, $365^{* *}$ \\
& Significance (2-sided) & &, 000 &, 000 \\
& $\mathrm{~N}$ & 150 & 150 & 150 \\
\multirow{5}{*}{ Factor 2 } & Correlation according to Pearson &,$- 437^{* *}$ & 1 &,- 160 \\
& Significance (2-sided) &, 000 & 150 &, 050 \\
& $\mathrm{~N}$ & 150 &,- 160 & 150 \\
\multirow{2}{*}{ Factor 3 } & Correlation according to Pearson &, $365^{* *}$ &, 050 & 1 \\
& Significance (2-sided) &, 000 & 150 & 150 \\
\hline
\end{tabular}

** The correlation is significant at the level of 0.01 (-2 sided).

This figure shows thatFactors 1 and 2 correlate highly significantly with each other, but negatively. This could mean that bothFactors measure something similar, but of different quality or educational level, perhaps something like a general motivational system, where knowledge or belief are only the different dimensions. The $3^{\text {rd }}$ Factor also correlates at the 0.01 significance level withFactor 1 but not withFactor 3 (-
.160). However, if one calculates a correlation according to Spearman-Rho (nonparametric correlation), the $3^{\text {rd }}$ Factor also correlates with theFactor $2(-, 164)$ at a 0.05 level, but negatively. This could mean that item 1 may represent both dimensions, but in opposite quality.

Due to the fact that Item 1 loads on a singleFactor, no reliability could be calculated for thisFactor. That's why this 
item was left out of the 2 -factor solution. Item no. 11 was also taken into account in the 2-factor solution. Once it was calculated with item no. 11, once without the item. Both solutions are briefly presented (see Table 4).

Table 4. Declared total variance of the 2-factor solution with item no. 11.

\begin{tabular}{llllll}
\hline \multirow{2}{*}{ Component } & \multicolumn{2}{l}{ Initial eigenvalues } & \multicolumn{3}{l}{ Sums of squared Factor charges for extraction } \\
\cline { 2 - 6 } & Total & \% of variance & Accumuleted\% & Total & \% of variance \\
\hline 1 & 5,085 & 42,376 & 42,376 & 5,085 & 42,376 \\
2 & 1,666 & 13,884 & 56,260 & 1,666 & 13,884 \\
3 &, 888 & 7,402 & 63,663 & & \\
\hline
\end{tabular}

Extraction Method: Principal Component Analysis.

ThisFactor analysis explains $56.260 \%$ of the total variance with the twoFactors. With the corresponding rotated component matrix it can be seen that item no. 11, just as with the 3 -factor solution, charges theFactor 1 , but negatively and in comparison with the other items thisFactor, with the lowest charge (see Table 5).

Table 5. Rotated component matrix of the 2-factor solution with item no. 1.

\begin{tabular}{lll}
\hline & Komponente \\
\cline { 2 - 2 } & $\mathbf{1}$ \\
\hline FEB Question 3 Double stitched hold better &, 810 \\
FEB Question 10 Trust ist good, control is better &, 796 \\
FEB Question 12 I only belief, what i see &, 765 \\
FEB Question 14 Knowledge make safe &, 751 \\
FEB Question 5 Safe is safe &, 722 \\
FEB Question 4 Knowledge is more important than faith &, 711 \\
FEB Question 11 Fantasy is more important is than knowledge &,- 589 \\
FEB Question 6 Faith moves mountains &, 774 \\
FEB Question 9 Confidence gives courage &, 738 \\
FEB Question 7 Hope dies last &, 699 \\
FEB Question 8 Dreams come true &, 639 \\
FEB Question 2 Optimists live easier &, 632 \\
\hline
\end{tabular}

Extraction method: principal component analysis.

Rotation method: Varimax with Kaiser normalization.

In the subsequent correlation ofFactors 1 and 2, it can also be seen that bothFactors correlate very strongly with each other, but negatively, just as in the 3-factor solution, even with the same coefficient (see Table 6).

Table 6. Correlation of the 2-factor solution with item no. 11.

\begin{tabular}{llll}
\hline & & Factor 1 & Factor 2 \\
\hline \multirow{3}{*}{ Factor 1 } & Correlation according to Pearson & 1 &,$- 437 * *$ \\
& Significance (2-sided) & 150 &, 000 \\
Factor 2 & $\mathrm{N}$ &,$- 437 * *$ & 150 \\
& Correlation according to Pearson &, 000 & 1 \\
\hline
\end{tabular}

** The correlation is significant at the level of 0.01 ( -2 sided).

For the 2-factor solution without item no. 11, the followingFactor structure results (see Table 7).

Table 7. Explained total variance of the 2-factor solution or item no. 11.

\begin{tabular}{llllll}
\hline \multirow{2}{*}{ Component } & \multicolumn{2}{l}{ Initial eigenvalues } & \multicolumn{3}{c}{ Sums of squared Factor charges for extraction } \\
\cline { 2 - 6 } & Total & \% of variance & Accumuleted\% & Total & \% of variance \\
\hline 1 & 4,768 & 43,342 & 43,342 & 4,768 & 43,342 \\
2 & 1,651 & 15,006 & 58,348 & 1,651 & 15,006 \\
3 &, 849 & 7,717 & 66,065 & & \\
\hline
\end{tabular}

Extraction Method: Principal Component Analysis.

In this Factor analysis, the twoFactors explain $58.348 \%$ of the total variance

As can also be seen from this rotated component matrix, the Factor charges have changed only minimally compared to the two previously calculatedFactor solutions. Also, as far as the correlation of the twoFactors is concerned, there is only a minimal difference between the correlation coefficients and the previous correlations. Here, too, bothFactors correlate highly significantly $(-.473)$ at the 0.01 significance level. This leads to the conclusion that all 3 solutions do not differ 
significantly, and that the construct validity of this test and can be described as very good (see table 8). instruments meets the requirements of classical test theory

Table 8. Correlation of the 2-factor solution or item no. 1.

\begin{tabular}{llll}
\hline & & Factor 1 & Factor 2 \\
\hline \multirow{3}{*}{ Factor 1} & Correlation according to Pearson & 1 &,$- 473^{* *}$ \\
& Significance (2-sided) & &, 000 \\
\multirow{2}{*}{ Factor 2} & $\mathrm{~N}$ & 150 & 150 \\
& Correlation according to Pearson &,$- 473^{* *}$ & 1 \\
& Significance (2-sided) &, 000 & 150 \\
\hline
\end{tabular}

** The correlation is significant at the level of 0.01 (-2 sided).

If we split the questionnaire into two shorts questionaires with the respective itrems of the 2 differentFactors (items of knowledge or items of faith) and calculate a seperateFactor analysis for each, Factor 1 in this concrete case would even explain $62.550 \%$ andFactor $252,132 \%$ of the total variance (see tables 9 and 10 ).

Table 9. Explained total variance of Factor 1.

\begin{tabular}{llllll}
\hline \multirow{2}{*}{ Component } & \multicolumn{2}{l}{ Initial eigenvalues } & \multicolumn{3}{l}{ Sums of squared factor charges for extraction } \\
\cline { 2 - 5 } & Total & \% of variance & Accumuleted\% & Total & \% of variance \\
\hline 1 & 3,753 & 62,550 & 62,550 & 3,753 & 62,550 \\
2 &, 599 & 9,982 & 72,532 & & 62,550 \\
\hline
\end{tabular}

Extraction Method: Principal Component Analysis.

Table 10. Explained total variance of Factor 2.

\begin{tabular}{llllll}
\hline \multirow{2}{*}{ Component } & \multicolumn{2}{l}{ Initial eigenvalues } & \multicolumn{3}{l}{ Sums of squared Factor charges for extraction } \\
\cline { 2 - 6 } & Total & \% of variance & Accumuleted\% & Total & \% of variance \\
\hline 1 & 2,607 & 52,132 & 52,132 & 2,607 & 52,132 \\
2 &, 836 & 16,724 & 68,855 & & \\
\hline
\end{tabular}

Extraction Method: Principal Component Analysis.

As a summary of the results of the variousFactor solutions to date, we can state that the self-evaluation questionnaire (FEB) is a valid instrument that validly measures intraindividual, action-guiding persuasion schemes or motivation dimensions in the sense of "knowledge" and "belief".

\subsection{Results of the Reliability Calculation}

For the calculation of the reliability of the questionnaire, i.e. how well and reliably it measures this theoretical construct, the items are used that were also taken into account in the 2-factor solution (or Item No. 11). The following table shows that Cronbach's alpha for the complete questionnaire is .572. This value does not appear to be very high (see Table 11).

Table 11. Item scale statistics (total test).

\begin{tabular}{|c|c|c|c|c|}
\hline & Scala Mean if Item Deleted & $\begin{array}{l}\text { Scala Variance if } \\
\text { Item Deleted }\end{array}$ & $\begin{array}{l}\text { Corrected Item } \\
\text { Total } \\
\text { Correlation }\end{array}$ & $\begin{array}{l}\text { Cronbachs } \\
\text { Alpha if Item } \\
\text { Deleted }\end{array}$ \\
\hline FEB Question 6 Faith moves mountains & 28,02 & 15,241 &,- 094 & ,617 \\
\hline FEB Question 7 Hope dies last & 27,78 & 15,663 &,- 168 & 638 \\
\hline FEB Question 8 Dreams come true & 28,09 & 15,186 &,- 091 & 620 \\
\hline FEB Question 9 Confidence gives courage & 27,69 & 15,100 &,- 074 & ,615 \\
\hline FEB Question 3 Double stitched hold better & 27,33 & 11,821 & ,563 & ,475 \\
\hline FEB Question 5 Safe is safe & 27,29 & 12,206 &, 454 & ,499 \\
\hline FEB Question 10 Trust is good, control is better & 27,26 & 11,657 &, 546 & ,474 \\
\hline FEB Question 12 I only beliefe, what i see & 27,44 & 11,550 & ,446 & ,491 \\
\hline FEB Question 4 Knowledge make safe & 27,24 & 12,224 & ,437 &, 502 \\
\hline $\begin{array}{l}\text { FEB Question } 1 \text { Faith means to know nothing } \\
\text { Cronbachs Alpha }=, 572 \mathrm{~N} \text { of Cases }=150 \mathrm{~N} \text { of Items }=11\end{array}$ & 28,03 & 11,919 & ,319 &, 528 \\
\hline
\end{tabular}

However, if we look at the respective selectivity coefficients of the individual items, we can see that the items of the $2^{\text {nd }}$ Factor have a negative value and thus massively reduce the reliability of the questionnaire. For this reason, it seems reasonable to calculate the reliability of eachFactor (1+2) for itself (see Tables 12 and 13). 
Table 12. Item Scale Statistics for Factor 1.

\begin{tabular}{lllll}
\hline & $\begin{array}{l}\text { Scala Mean if } \\
\text { Item D. }\end{array}$ & $\begin{array}{l}\text { Scala Variance } \\
\text { Item Deleted }\end{array}$ & $\begin{array}{l}\text { Corrected Item } \\
\text { Correlation }\end{array}$ & $\begin{array}{l}\text { Total } \\
\text { Cronbachs Alpha } \\
\text { if Item Deleted }\end{array}$ \\
\hline FEB Question 3 Double stitched hold better & 15,15 & 10,609 &, 710 &, 855 \\
FEB Question 4 Knowledge is more important than faith & 15,24 & 10,466 &, 663 &, 862 \\
FEB Question 5 Safe is safe & 15,10 & 10,601 &, 678 &, 859 \\
FEB Question 10 Trust is good, control is better & 15,07 & 10,243 &, 733 &, 850 \\
FEB Question 12 I only beliefe what i see & 15,25 & 9,439 &, 749 &, 848 \\
FEB Question 14 Knowledge make safe & 15,05 & 10,896 &, 593 &, 873 \\
Cronbachs Alpha =,879 N of Cases =150 N of Items =6 & & & & \\
\hline
\end{tabular}

Table 13. Item Scale Statistics for Factor 2.

\begin{tabular}{lllll}
\hline & $\begin{array}{l}\text { Scala Mean if Item } \\
\text { Deleted }\end{array}$ & $\begin{array}{l}\text { Scala Variance if } \\
\text { Item Deleted }\end{array}$ & $\begin{array}{l}\text { Corrected Item } \\
\text { Total Correlation }\end{array}$ & $\begin{array}{l}\text { Cronbachs Alpha } \\
\text { if Item Deleted }\end{array}$ \\
\hline FEB Question 2 Optimists live easier & 9,85 & 5,347 &, 477 &, 746 \\
FEB Question 6 Faith moves mountains & 10,10 & 5,312 &, 617 &, 697 \\
FEB Question 7 Hope dies last & 9,86 & 5,141 &, 585 &, 706 \\
FEB Question 8 Dreams come true & 10,17 & 5,607 &, 746 &, 721 \\
$\begin{array}{l}\text { FEB Question 9 Conifidence gives courage } \\
\text { Cronbachs Alpha =,766 N of Cases = 150 N of Items }=\end{array}$ & 9,77 & 5,438 &, 543 & \\
5 & & & & \\
\hline
\end{tabular}

When calculating the reliability for theFactor 1 we get a Cronbach's Alpha $=.879$. ( see Table 12).

This coefficient can be described as particularly high. This means thatFactor 1 reliably measures the theoretical construct "knowledge" as schemata guiding action.

As can be seen from the table, the Cronbach's Alpha with .766 is also very good for the $2^{\text {nd }}$ Factor, which is a good indicator for the reliability of the $2^{\text {nd }}$ Factor i. H. on the criterion to be measured "faith" in the sense of an intraindividual, action guiding conviction (see table 13).

\section{Summary and Interpretation of the Test Theoretical Results of the Self-Developed Questionnaire (FEB)}

\subsection{Questioning}

A specific questionnaire was developed in order to objectively record the different preferences for knowledge and belief. With the help of this questionnaire an individual, latent, inner attitude scheme, a kind of motive in the sense of "need to know" or "want to believe" should be determined. The items used were taken from common usage and subjected to a careful item analysis with regard to their selectivity.

\subsection{Statistical Analysis Method}

The validity of the test instrument was calculated by aFactor analysis with main component analysis as traction method and with Varimax Kaiser normalization as rotation method. A 3- and 2-factor solution was calculated, which respectively explain $60.893 \%$ and $58.348 \%$ of the total variance. Although the 3 -factor solution has a minimally better explantion of the total variance, but the $3^{\text {rd }}$ Factor loads only on a single item, so that no reliability calculation could be carried out according to the principles of the classical test theory, an interpretation in favour of the 2-factor solution was dispensed with.

The 2-factor solution clearly has two independentFactors, each of which can be described as a

Preference or motivation for knowledge (knowlwdgwFactor) and a motivation for faith (faithFactor). A conformation of this model can also foud in the $\%$ figures of the declared total variance in theFactor analyses of the individualFactors and results of theFactor correlations.

The reliability of the questionnaire for the recording of Beliefsystems (FEB) was calculated with the help of Cronbach's Alpha, once for the overall test and once for both test halves (knowledge items or faith items) separately. The reliability of the overall test is .572 which does not seem so high. On closer inspection, however, we can see that the faith items have negative discriminatory power coefficients and thus greatly reduce the reliability score of the overall test. In a separate calculation, particularly high or very good values were obtained for the Cronbach's alpha (cf. item scale statistics forFactor 1 (knowledge) Cronbach's alpha .879 and forFactor 2 (faith) equal to .766 .

Due to the highly significant correlations or partial correlations with the standardised test procedures (BDI, BAI, SWSF and HAKI-S), FEB also has very good criterion validity. From a test theoretical point of view, the validity as well as the reliability of the test instrument with regard to an objective measurement of the two preferences (knowledge and belief) could thus be proven.

TheFEB is a useful, valid and reliable instrument for scientific research with regard to individual motivation to want to believe or to have to know. This questionnaire can be a good help for the scientific discussion and thus provide an empirical gain of knowledge. 
Table 14. Questionnaire for the registration of Belief systems (FEB).

\begin{tabular}{|c|c|c|c|c|}
\hline $\begin{array}{l}\text { Questionnaire No: } \\
\text { Age: } \quad \text { Years: } \\
\text { Occupation: }\end{array}$ & \multicolumn{2}{|c|}{$\begin{array}{l}\text { Date: } \\
\text { Gender: (w) (m) } \\
\text { Group: }\end{array}$} & & \\
\hline \multicolumn{5}{|c|}{ Please read through the following phrases and cross them afterwards the answer you which, in your opinion, is most likely to apply to you } \\
\hline & right & right & right & right \\
\hline & not & something & often & always \\
\hline 1. Faith means to know nothing & ( ) & ( ) & ( ) & ( ) \\
\hline 2. Optimists live easier & ( ) & ( ) & ( ) & ( ) \\
\hline 3. Double stitched hold better & ( ) & ( ) & ( ) & ( ) \\
\hline 4. Knowledge is more important than faith & ( ) & ( ) & ( ) & ( ) \\
\hline 5. Safe is safe & ( ) & ( ) & ( ) & ( ) \\
\hline 6. Faith moves mountains & ( ) & ( ) & ( ) & ( ) \\
\hline 7. Hope dies last & ( ) & ( ) & ( ) & ( ) \\
\hline 8. Dreams come true & ( ) & ( ) & ( ) & ( ) \\
\hline 9. Conifidence gives courage & ( ) & ( ) & ( ) & ( ) \\
\hline 10. Trust is good, control is better & ( ) & ( ) & ( ) & ( ) \\
\hline 12. I beliefe what i see & ( ) & ( ) & ( ) & ( ) \\
\hline 13. Will already be & ( ) & ( ) & ( ) & ( ) \\
\hline 14. Knowledge make safe & ( ) & ( ) & ( ) & ( ) \\
\hline 15. Nothing to belief is impossible & () & () & () & () \\
\hline
\end{tabular}

\section{References}

[1] Collier, A. (1713). Clavio Universalis, p. 6 f..

[2] Hume, D. (1748) An Enquiry Concerning Human Understanding, übersetzt v. J. H. v. Kirchmann, 1869, Abt. V., Skeptische Lösung dieser Zweifel, Abschnitt II, S. 48-50, Berlin: L.

[3] Hume, D. (2013). Eine Untersuchung in Betreff des menschlichen Verstandes. CreateSpace Independent Publishing Platform. Übersetzt, erläutert und mit einer Lebensbeschreibung versehen von J. H. von Kirchmann: Berlin, L. Heimann, 1869 (Philosophische Bibliothek, Bd. 13).

[4] Jacobi, F. (1743-1819). Werke 1812-1815. Band II. "David Hume über den Glauben oder Idealismus und Realismus”, S. $109 \mathrm{ff}$.

[5] Reinhold, E. (1832). Theorie des menschlichen Erkenntnisvermögens In: Theorie des menschlichen Erkenntnisvermögens und Metaphysik. Bd. 1, Hennings' sche Buchhand-lung, Gotha und Erfurt, S. 124.

[6] Fries, J. F. (1837). System der Logik, Ein Handbuch für Lehrer und zum Selbstgebrauch, Heidelberg, 3. A., Christian Friedrich Winter, S. 421.

[7] Schleiermacher, F., (1839). Dialektik, aus Schleiermachers handschriftlichem Nachlasse, Hrsg. von L. Jonas, Reimer, Berlin, S. 93.

[8] Herbart, J. F. (1850). Lehrbuch zur Psychologie. 3. Auflage, Hrsg: G. Hartenstein, Leipzig, Voss, S. 65.

[9] Schelling, F. W. J. (1856-61). Sämtliche Werke, Hrsg. K. F. A. Schelling, Stuttgart, I. Abtlg. Band 10, S. 183.

[10] Locke, J. (1873). An Analysis of Locke's Essay on the Human Understanding, Dublin; Cook Wilson, Journal of Statement and Inference. Vol. II.

[11] Locke, J. (2000). Versuch über den menschlichen Verstand,
Bd. 1., Buch I und II, 5., Aufl., Hamburg, Meiner.

[12] Hagemann, G. (1873). Logik. und Noetik, 3. Auflage, Münster Russell, 1873 S. 161.

[13] Kant, E., (1877). Log. S. 101, S. 102, Krit. d. Urt. § 91, S. 132, Üb. d. Fortschr. d. Met. S. 142, Log. S. 110, Kr. d. r. Vern. S. 623, 624, 626; WW. IV, 347; Kr. d. Urt. § 91 ff.).

[14] Wundt, W. (1880). Logik, I. Band, Erkenntnislehre, Verlag von Ferdinand Enke; Stuttgart, S. 370, 372, 377.

[15] Kirchner, Fr. (1890). Wörterbuch der philosophischen Grundbegriffe. Georg Weiss Verlag, Heidelberg, S. 153 u. 154.

[16] Kirchner, F. \& C. Michaelis, C. Felix Meiner F. (2013). Wörterbuch der philosophischen Grundbegriffe. Hamburg, S. 2.

[17] James, W. (1890). The principles of psychology. New York: Holt.

[18] James, W. (1891). The Principles of Psychology. 2 Bände. Holt and Macmillan, New York/London, II. Band, S. 282.

[19] James, W. (1899). Wille zum Glauben und andere popularphilosophische Essays. Fr. From-manns Verlag (E. Hauff), Stuttgart; S. $60 \mathrm{ff}$.

[20] Jerusalem, W. (1895). Die Urteilsfunktion. Eine psychologische und erkenntniskritische Untersuchung, W. Braumüller, Wien \& Leipzig, S. 199).

[21] Jerusalem, W. (1903). Lehrbuch der Psychologie 3. Auflage, Wilh. Braumüller, Wien u. Leipzig, S. 124; Die Urteilsfunktionen. S. o., S. 200.

[22] Drobisch, M. W. (1887). Neue Darstellung der Logik nach ihren einfachsten Verhältnissen mit Rücksicht auf Mathematik und Naturwissenschaft. 5. Aufl. Hamburg und Leipzig, § 156.

[23] Mach, E. (1905). Erkenntnis und Irrtum. Skizzen zur Psychologie der Forschung. A. Barth, Leipzig, S. 113.

[24] Eisler, R. (1910). Wörterbuch der philosophischen Begriff, Band 1, S. 439, Siegried Mittler und Sohn, Königliche Hofbuchhandlung, Berlin. 
[25] Eisler, R. (1910). Wörterbuch der philosophischen Begriffe. Mittler \& Sohn, Berlin, S. 438.

[26] Hintikka, J. (1962). Knowledge and Belief. An Introduction to the Logic of the Two Notions, Cornell, University Press.

[27] Swinburne, R. (1979, 2004). The Existence of God, Oxford, Clarendon Press.

[28] Coleman, J. (1982). Systems of trust, A rough theoretical framework. Angewandte Sozial-forschung, (10), S. 302.

[29] Coleman, J. (1990). Foundations of social theory, Cambridge, Mass. and London, Belknap Press, p. 99; 100.

[30] Coleman, J. (1991). Grundlagen der Sozialtheorie. Band 1. Handlungen und Handlungssysteme. München: Oldenbourg, S. 12.

[31] Stich, S. (1983). From Folk Psychology to Cognitive Science: The Case Against Belief. MIT Press.

[32] Outram, D. (1995). The Enlightenment. Cambridge, Cambridge University Press, p. 3.

[33] Baker, L. R. (1998). “The First-Person Perspective”: A Test for Natuarlism Philosophical Quarterly, 35, S. 327-348.

[34] Schulz, H. (2001). Theorie des Glaubens. Mohr Siebeck, Tübingen, §1, S. 11, S. 50, 302 ff., S. 443-444).

[35] Sturma, D. (2006). Ausdruck von Freiheit. Über Neurowissenschaften und die menschliche Lebensform, in: Dieter Sturma (Hg.), Philosophie und Neurowissenschaften, Frankfurt/M. S. 195.

[36] Möllering, G. (2005). Das Aufheben von Ungewissheit als Kern des Vertrauens: Just do it? Max-Planck-Instituts für Gesellschaftsforschung, S. 77.

[37] Möllering, G. (2006/2007). Grundlagen des Vertrauens: Wissenschaftliche Fundierung eines Alltagsproblem. Why do we trust, A theoreticel approach to an everyday problem, MaxPlanck-Institut für Gesellschaftsforschung, Köln.

[38] Szanto, T. (2012) Bewusstsein, Intentionalität und mentale Repräsentation. Husserl und die analytische Philosophie des Geistes. Berlin/Boston: De Gruyter, S. 121 ff.

[39] Kirchner, Fr. (1890). Wörterbuch der philosophischen Grundbegriffe. Georg Weiss Verlag, Heidelberg, S. 153 u. 154.

[40] Kirchner, F. \& C. Michaelis, C. Felix Meiner F. (2013). Wörterbuch der philosophischen Grundbegriffe. Hamburg, S. 2.

[41] Regenbogen A., Meyer, U. (2013). Wörterbuch der philosophischen Begriffe, Hamburg, Felix Meiner Verlag, S. 707.

[42] Platon, (428-348 v. Ch.), Theaitetos, Sämtliche Werke. Band 2, Berlin [1940], S. 561-662.

[43] Platon, (2005). Apologie 21a-22a, Übersetzung von Friedrich Schleiermacher, bearb. von Heinz Hofmann, 5. Aufl., Darmstadt, WBG.

[44] Aristoteles (384-322 v. Ch.). Metaphysik Berliner Ausgabe, 2016, 4. Auflage, Taschenbuch, Edition Holzinger.

[45] Gawlick, G. (1992) "Rationalismus I", in: Historisches Wörterbuch der Philosophie, HWPh Bd. 8 S. 30301 bzw.
HWPh Bd. 8, S. 44.

[46] Arendt, H. (2002) Vita activa oder vom tätigen Leben. München, Zürich, Piper.

[47] Russell, B. (1912) The Problems of Philosophy, in dt. Probleme der Philosophie, (2007) Berlin, Suhrkamp Verlag.

[48] Russell, B. (2007). The Problems of Philosophy, 1912, in dt. Probleme der Philosophie, Frankfurt, Suhrkamp Verlag.

[49] Goldman, A. (1973) Discrimination and Perceptual Knowledge, in: The Journal of Philosophy.

[50] Goldmann, A. (1967). A Causal Theory of Knowing. In: The Journal of Philosophy v. 64, pp. 335-372.

[51] Stegmüller, W. (1969). Hauptströmungen der Gegenwartsphilosophie, Stuttgart, Alfred Kröner Verlag, S. 398.

[52] Armstrong, D. M. (1973). Belief, Truth a. Knowledge. London, Cambridge University Press.

[53] Popper, K. (1979). Die beiden Grundprobleme der Erkenntnistheorie. Tübingen, Verlag, J. C. B. Mohr (Paul Siebeck).

[54] Sigmund, K. (2015) Sie nannten sich der Wiener Kreis, Springer Spektrum.

[55] Mittelstraß, J. und Kambartel F. (1973). Zum Normativen Fundament der Wissenschaft. Frankfurt, Athenäum.

[56] Glasersfeld, E. v. (1992). Konstruktion der Wirklichkeit und der Begriff der Objektivität; in: Foerster, H. v. et al., (1992), Einführung in den Konstruktivismus, Veröffentlichungen der Carl-Friedrich-von-Siemens-Stiftung 5, München, Zürich, Piper S. 12.

[57] Glasersfeld, E. v. (1996). Der Radikale Konstruktivismus. Ideen, Ergebnisse, Probleme, Ffm, Suhrkamp, S. 55, S. 190.

[58] Glasersfeld, E. v. (2012). Einführung in den radikalen Konstruktivismus, in P. Watzlawick, die erfundene Wirklichkeit, (2012), München, Piper, S. 23.

[59] Lorenz, K. (2009). Dialogischer Konstruktivismus. Berlin, Walter de Gruyter.

[60] Ameln, F. v. (2004). Konstruktivismus, Die Grundlagen systemischer Therapie, Beratung und Bildungsarbeit, Tübingen, UTB.

[61] Foerster, H. v. (2006). Einführung in den Konstruktivismus. München, Piper.

[62] Foerster, H. v. (2012). Das Konstruieren einer Wirklichkeit, in P. Watzlawick, Die erfundene Wirklichkeit, München, Piperverlag, 2006, S. 39, 40.

[63] Lorenz, K. (2009). Dialogischer Konstruktivismus. Berlin, Walter de Gruyter.

[64] Schlageter, W. (2013) Wissen im Sinne der Wissenschaften. Frankfurt, August von Goethe Literaturverlag, S. 114, 313, 395. 
Biography

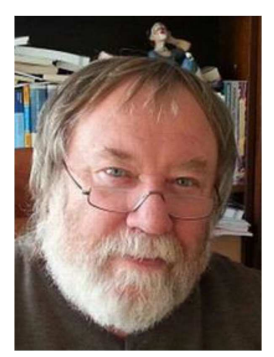

Dipl Psych Josef Wacker, PhD, Clinical Psychologist Approved psychotherapist and psychotherapist Psychotherapist for children and adolescents, Behavioural therapist. 